\section{Eastern Association for the Surgery of Trauma firearm injury prevention statement}

\author{
Eastern Association for the Surgery of Trauma
}

Firearm violence is a public health crisis of epidemic proportions. Over 30000 Americans die from gunshot wounds every year, and countless others are injured.

Surgeons and trauma care providers are a diverse group, encompassing a wide range of ages, all sexes, all races and ethnicities, and differing political beliefs. At the Eastern Association for the Surgery of Trauma (EAST), we feel that our current efforts to reduce firearm-related injuries and violence are insufficient. EAST believes that saving individual lives without addressing the underpinnings of violence and the obvious vector, firearms, is contributing to the ongoing suffering.

Therefore, as an organization of providers who care for the patient with injuries, and specifically victims of firearm injury, we are committed to the health and safety of our patients and their communities. EAST makes the following statement:

Firearm-related injury and death are a complex public health problem.

- EAST supports evidence-based strategies to reduce firearm injuries including the following:

- Federal funding of firearm-related research to inform solutions.

- Violence and injury prevention programs that address conflict resolution.

- Programs that teach non-violent conflict resolution, coping strategies, and anger management.

- Improved access and quality of mental health services.

- Recognition of the other factors that affect these issues including structural violence, domestic violence, and mental health.

- Limited access to firearms through mandatory safe storage (keeping guns unloaded in a safe with ammunition stored in a separate locked device), gun locks, trigger locks, and other safe storage practices.

Correspondence to Eastern Association for the Surgery of Trauma, Chicago, IL 60611, USA; ceme@ east.org
- Expanded universal background checks to include all firearms sales in any venue.

- Mandatory waiting periods and universal background checks for acquisition of firearms.

- Limited civilian access to highly lethal firearms and firearm accessories, such as high velocity rifles, high-capacity magazines, trigger cranks, and bump stocks.

- Limited dissemination of technology to enhance lethality or bypass standard safety and/or screening (eg, three-dimensional printing firearms).

We hope you will join EAST to develop non-partisan and evidence-based solutions for our patients. Standing by and becoming increasingly numb to the rising injury and death toll being witnessed across this country is not an option. Please stand with EAST to affect change.

\section{SUPPORTING STATEMENTS}

American College of Surgeons https:// www.facs.org/quality-programs/trauma/ violenceprevention

American College of Surgeons Committee on Trauma Consensus-Based Approach to Firearm Injury: An Introduction http://bulletin.facs.org/2017/10/ a-consensus-basedapproach-to-firearminjury/

American Association for the Surgery of Trauma https://journals.lww.com/jtrauma/ Citation/publishahead/AAST_Statement on_Firearm_Injury.98601.aspx/

Society of American Gastrointestinal and Endoscopic Surgeons https://www. sages.org/statement-firearm-safety/

American Trauma Society https://www. amtrauma.org/page/PosState132?? https:// www.amtrauma.org/news/409018/ATSSubmitsComment-to-ATF.htm

Funding The authors have not declared a specific grant for this research from any funding agency in the public, commercial or not-for-profit sectors.

Editor's note Approved by the EAST Board of Directors September 25, 2018 as was in the original PDF.

Competing interests None declared.

Patient consent Not required.
Ethics approval This Study has been approved by the EAST Board of Directors, September 26, 2018.

Provenance and peer review Commissioned; internally peer reviewed.

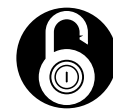

\section{OPEN ACCESS}

Open access This is an open access article distributed in accordance with the Creative Commons Attribution Non Commercial (CC BY-NC 4.0) license, which permits others to distribute, remix, adapt, build upon this work non-commercially, and license their derivative works on different terms, provided the original work is properly cited, appropriate credit is given, any changes made indicated, and the use is non-commercial. See: http:// creativecommons.org/licenses/by-nc/4.0

(c) Author(s) (or their employer(s)) 2019. Re-use permitted under CC BY-NC. No commercial re-use. See rights and permissions. Published by BMJ.

\section{Check for updates}

To cite Trauma Surg Acute Care Open 2019;4:e000294. doi:10.1136/tsaco-2018-000294

Received 31 December 2018

Accepted 31 December 2018

Trauma Surg Acute Care Open 2019;4:e000294. doi:10.1136/tsaco-2018-000294

\section{REFERENCES}

1. Violence in America: a public health crisis--the role of firearms. the violence prevention task force of the Eastern Association for the Surgery of Trauma. J Trauma 1995;38:163-8.

2. Aneja A, Donohue JJ, Zhang A. The impact of rightto-carry laws and the NRC report: lessons for the empirical evaluation of law and policy. American Law and Economics Review 2011;13:565-631.

3. Armed forces health surveillance center (AFHSC). Deaths by suicide while on active duty, active and reserve components, U.S. armed forces, 1998-2011. MSMR 2012:19:7-10.

4. Azrael D, Hemenway D, Miller M, Barber CW, Schackner R. Youth suicide: insights from 5 years of Arizona child fatality review team data. Suicide Life Threat Behav 2004:34:36-43.

5. Brent DA, Perper JA, Allman CJ, Moritz GM, Wartella $M E$, Zelenak JP. The presence and accessibility of firearms in the homes of adolescent suicides. A casecontrol study. JAMA 1991;266:2989-95.

6. Chapman S, Alpers P, Agho K, Jones M, Australia's JM. Australia's 1996 gun law reforms: faster falls in firearm deaths, firearm suicides, and a decade without mass shootings. Inj Prev 2015;21:355-62.

7. Crandall CS, Jost PF, Broidy LM, Daday G, Sklar DP. Previous emergency department use among homicide victims and offenders: a case-control study. Ann Emerg Med 2004;44:646-55.

8. Crandall M, Eastman A, Violano P, Greene W, Allen $S$, Block E, Christmas AB, Dennis A, Duncan T, Foster $S$, et al. Prevention of firearm-related injuries with restrictive licensing and concealed carry laws: an eastern association for the surgery of trauma systematic review. J Trauma Acute Care Surg 2016:81:952-60.

9. Crifasi CK, Meyers IS, Vernick JS, Webster DW. Effects of changes in permit-to-purchase handgun laws in Connecticut and Missouri on suicide rates. Prev Med 2015;79:43-9 
10. Crifasi CK, Pollack KM, Webster DW. Effects of state-level policy changes on homicide and nonfatal shootings of law enforcement officers. Inj Prev 2016:22:274-8.

11. Culyba AJ, Miller E, Ginsburg KR, Branas CC, Guo W, Fein JA, Richmond TS, Halpern-Felsher BL, Wiebe DJ. Adult connection in assault injury prevention among male youth in low-resource urban environments. J Urban Health 2018;95:361-71.

12. Cummings P, Grossman DC, Rivara FP, Koepsell TD. State gun safe storage laws and child mortality due to firearms. JAMA 1997;278:1084-6.

13. Cummings P, Grossman DC, Rivara FP, Koepsell TD. State gun safe storage laws and child mortality due to Firearms. JAMA 1997:278:1084-6.

14. Cummings P, Koepsell TD, Grossman DC, Savarino J, Thompson RS. The association between the purchase of a handgun and homicide or suicide. Am J Public Health 1997:87:974-8.

15. Fleegler EW, Lee LK, Monuteaux MC, Hemenway D, Mannix R. Firearm legislation and firearm-related fatalities in the United States. JAMA Intern Med 2013;173:732-40.

16. Gani F, Sakran JV, Canner JK. Emergency department visits for firearm-related injuries in the United States, 2006-14. Health Aff 2017:36:1729-38.

17. Grinshteyn E, Hemenway D. Violent death rates: the US compared with other high-income OECD countries, 2010. Am J Med 2016;129:266-73.

18. Grossman DC, Cummings $P$, Koepsell TD, Marshall J, D'Ambrosio L, Thompson RS, Mack C. Firearm safety counseling in primary care pediatrics: a randomized, controlled trial. Pediatrics 2000;106:22-6.

19. Grossman DC, Mueller BA, Riedy C, Dowd MD, Villaveces A, Prodzinski J, Nakagawara J, Howard J, Thiersch N, Harruff R. Gun storage practices and risk of youth suicide and unintentional firearm injuries. JAMA 2005;293:707-14.

20. Grossman DC, Reay DT, Baker SA. Self-inflicted and unintentional firearm injuries among children and adolescents: the source of the firearm. Arch Pediatr Adolesc Med 1999;153:875-8.

21. Hemenway $D$, Azrael D. The relative frequency of offensive and defensive gun uses: results from a national survey. Violence Vict 2000;15:257-72.

22. Hemenway D, Miller andM. Firearm availability and homicide rates across 26 high-income countries. J Trauma 2000:49:985-8.

23. Hemenway D, Shinoda-Tagawa T, Miller M. Firearm availability and female homicide victimization rates among 25 Populous high-income countries. J Am Med Womens Assoc 2002;57:100-4.

24. Hemenway D, Solnick SJ. The epidemiology of self-defense gun use: evidence from the National crime victimization surveys 2007-2011. Prev Med 2015;79:22-7.

25. Hemenway $D$, Vriniotis M, Miller M. Is an armed Society a polite society? guns and road RAGE. Accid Anal Prev 2006:38:687-95.

26. Hepburn L, Azrael D, Miller M, Hemenway D. The Effect of Child Access Prevention Laws on Unintentional Child Firearm Fatalities, 1979???2000. The Journal of Trauma: Injury, Infection, and Critical Care 2006:61:423-8.

27. Hepburn L, Miller M, Azrael D, Hemenway D. The effect of nondiscretionary concealed weapon carrying laws on homicide. J Trauma 2004;56:676-81.

28. Hutson HR, Anglin D, Pratts MJ. Adolescents and children injured or killed in drive-by shootings in Los Angeles. N Engl J Med 1994;330:324-7.

29. Johnson RM, Barber C, Azrael D, Clark DE, Hemenway $D$. Who are the owners of firearms used in adolescent suicides? Suicide Life Threat Behav 2010;40:609-11.

30. Johnson RM, Miller M, Vriniotis M, Azrael D, Hemenway D. Are household firearms stored less safely in homes with adolescents?: analysis of a national random sample of parents. Arch Pediatr Adolesc Med 2006;160:788-92
31. Kellermann AL, Reay DT. Protection or peril? An analysis of firearm-related deaths in the home. $N$ Engl J Med 1986;314:1557-60.

32. Kellermann AL, Rivara FP, Lee RK, Banton JG Cummings P, Hackman BB, Somes G. Injuries due to firearms in three cities. $N$ Engl J Med 1996;335:1438-44.

33. Kellermann AL, Rivara FP, Rushforth NB, Banton JG, Reay DT, Francisco JT, Locci AB, Prodzinski J, Hackman BB, Somes G. Gun ownership as a risk factor for homicide in the home. $N$ Engl J Med 1993;329:1084-91

34. Kellermann AL, Rivara FP, Somes G, Reay DT, Francisco J, Banton JG, Prodzinski J, Fligner C, Hackman BB. Suicide in the home in relation to gun ownership. $N$ Engl J Med 1992;327:467-72.

35. Kellermann AL, Somes G, Rivara FP, Lee RK, Banton JG. Injuries and deaths due to firearms in the home. $J$ Trauma 1998:45:263-7.

36. Kercher C, Swedler DI, Pollack KM, Webster DW. Homicides of law enforcement officers responding to domestic disturbance calls. Inj Prev 2013;19:331-5.

37. Lee LK, Fleegler EW, Farrell C, Avakame E, Srinivasan S, Hemenway D, Monuteaux MC. Firearm laws and firearm homicides: a systematic review. JAMA Intern Med 2017:177:106-19.

38. Lewin NL, Vernick JS, Beilenson PL, Mair JS, Lindamood MM, Teret SP, Webster DW. The Baltimore youth ammunition Initiative: a model application of loca public health authority in preventing gun violence. $A m$ J Public Health 2005:95:762-5.

39. Miller M, Azrael D, Hemenway D. Rates of household firearm ownership and homicide across us regions and states, 1988-1997. Am J Public Health 2002:92:1988-93.

40. Miller M, Azrael D, Hemenway D. Firearm availability and suicide, homicide, and unintentional firearm deaths among women. J Urban Health 2002:79:26-38

41. Miller M, Azrael D, Hemenway D. Firearm availability and unintentional firearm deaths, suicide, and homicide among 5-14 year olds. J Trauma Acute Care Surg 2002; $52: 267-75$

42. Miller M, Azrael D, Hemenway D. Firearm availability and unintentional firearm deaths. Accid Anal Prev 2001:33:477-84.

43. Miller M, Azrael D, Hemenway D, Vriniotis M. Firearm storage practices and rates of unintentional firearm deaths in the United States. Accid Anal Prev 2005:37:661-7.

44. Miller M, Barber C, White RA, Azrael D. Firearms and suicide in the United States: is risk independent of underlying suicidal behavior? Am J Epidemiol 2013:178:946-55

45. Miller M, Hemenway D, Azrael D. State-level homicide victimization rates in the US in relation to survey measures of household firearm ownership, 2001-2003. Soc Sci Med 2007;64:656-64.

46. Miller M, Warren M, Hemenway D, Azrael D. Firearms and suicide in US cities. Inj Prev 2015;21(e1):e116-9.

47. Rosengart $M$, Cummings $P$, Nathens $A$, Heagerty $P$, Maier R, Rivara F. An evaluation of state firearm regulations and homicide and suicide death rates. Inj Prev 2005:11:77-83.

48. Rowhani-Rahbar A, Fan MD, Simonetti JA, Lyons VH, Wang J, Zatzick D, Rivara FP. Violence perpetration among patients hospitalized for unintentional and assault-related firearm injury: a case-control study and a cohort study. Ann Intern Med 2016:165:841-7.

49. Rowhani-Rahbar A, Simonetti JA, Rivara FP Effectiveness of interventions to promote safe firearm storage. Epidemiol Rev 2016;38:mxv006-24.

50. Rowhani-Rahbar A, Zatzick D, Wang J, Mills BM Simonetti JA, Fan MD, Rivara FP. Firearm-related hospitalization and risk for subsequent violent injury, death, or crime perpetration: a cohort study. Ann Intern Med 2015;162:492-500.
51. Rudolph KE, Stuart EA, Vernick JS, Webster DW. Association between Connecticut's Permit-toPurchase handgun law and homicides. Am J Public Health 2015;105:e49-54.

52. Sidman EA, Grossman DC, Koepsell TD, D'Ambrosio L, Britt J, Simpson ES, Rivara FP, Bergman AB. Evaluation of a community-based handgun safe-storage campaign. Pediatrics 2005;115:e654-61.

53. Simckes MS, Simonetti JA, Moreno MA, Rivara FP, Oudekerk BA, Rowhani-Rahbar A. Access to a loaded gun without adult permission and school-based bullying. J Adolesc Health 2017;61:329-34.

54. Simonetti JA, Mackelprang JL, Rowhani-Rahbar A, Zatzick D, Rivara FP. Psychiatric comorbidity, suicidality, and in-home firearm access among a nationally representative sample of adolescents. JAMA Psychiatry 2015;72:152-9.

55. Simonetti JA, Rowhani-Rahbar A, Mills B, Young $B$, Rivara FP. State firearm legislation and nonfatal firearm injuries. Am J Public Health 2015;105:1703-9.

56. Sloan JH, Kellermann AL, Reay DT, Ferris JA, Koepsell T, Rivara FP, Rice C, Gray L, LoGerfo J. Handgun regulations, crime, assaults, and homicide. A tale of two cities. N Engl J Med 1988;319:1256-62.

57. Sloan JH, Rivara FP, Reay DT, Ferris JA, Kellermann $A L$. Firearm regulations and rates of suicide. $A$ comparison of two metropolitan areas. N Engl J Med 1990:322:369-73.

58. Swedler DI, Simmons MM, Dominici F, Hemenway D. Firearm prevalence and homicides of law enforcement officers in the United States. Am J Public Health 2015;105:2042-8.

59. Tashiro J, Lane RS, Blass LW, Perez EA, Sola JE. The effect of gun control laws on hospital admissions for children in the United States. J Trauma Acute Care Surg 2016:81(4 Suppl 1):S54-S60.

60. Tasigiorgos S, Economopoulos KP, Winfield RD, Sakran JV. Firearm injury in the United States: an overview of an evolving public health problem. J Am Coll Surg 2015;221:1005-14.

61. Vernick JS, O'Brien M, Hepburn LM, Johnson SB, Webster DW, Hargarten SW. Unintentional and undetermined firearm related deaths: a preventable death analysis for three safety devices. Inj Prev 2003;9:307-11.

62. Vernick JS, Webster DW, Hepburn LM. Effects of Maryland's law banning Saturday night special handguns on crime guns. Inj Prev 1999; 5:259-63

63. Villaveces A, Cummings P, Espitia VE, Koepsell TD, McKnight B, Kellermann AL. Effect of a ban on carrying firearms on homicide rates in 2 Colombian cities. JAMA 2000:283:1205-9.

64. Violano $P$, Bonne $S$, Duncan T, Pappas $P$, Christmas AB, Dennis A, Goldberg S, Greene W, Hirsh M, Shillinglaw $W$, et al. Prevention of firearm injuries with gun safety devices and safe storage: an eastern association for the surgery of trauma systematic review. J Trauma Acute Care Surg 2018;84:1003-11.

65. Webster D, Crifasi CK, Vernick JS. Effects of the repeal of Missouri's handgun purchaser licensing law on homicides. J Urban Health 2014;91:293-302.

66. Webster DW, Gainer PS, Champion HR. Weapon carrying among inner-city junior high school students: defensive behavior vs aggressive delinquency. Am J Public Health 1993; 83:1604-8.

67. Webster DW, Starnes M. Reexamining the association between child access prevention gun laws and unintentional shooting deaths of children. Pediatrics 2000;106:1466-9.

68. Webster DW, Vernick JS, Hepburn LM. Effects of Maryland's law banning "Saturday night special" handguns on homicides. Am J Epidemiol 2002;155:406-12.

69. Webster DW, Vernick JS, Hepburn LM. Relationship between licensing, registration, and other gun sales 
laws and the source state of crime guns. Inj Prev 2001;7:184-9.

70. Webster DW, Vernick JS, Zeoli AM, Manganello JA. Association between youth-focused firearm laws and youth suicides. JAMA 2004;292:594-601.

71. Webster DW, Wintemute GJ. Effects of policies designed to keep firearms from high-risk individuals. Annu Rev Public Health 2015;36:21-37.

72. Whitehill JM, Webster DW, Frattaroli S, Parker EM. Interrupting violence: how the CeaseFire program prevents imminent gun violence through conflict mediation. J Urban Health 2014:91:84-95.

73. Wintemute GJ, Frattaroli S, Claire BE, Vittes KA Webster DW. Identifying armed respondents to domestic violence restraining orders and recovering their firearms: process evaluation of an initiative in California. Am J Public Health 2014;

104:e113-8.

74. Wintemute GJ, Parham CA, Beaumont JJ, Wright M, Drake C. Mortality among recent purchasers of handguns. N Engl J Med 1999;341:1583-9.
75. Zeoli AM, McCourt A, Buggs S, Frattaroli S, Lilley $D$, Webster DW. Analysis of the strength of legal firearms restrictions for perpetrators of domestic violence and their associations with intimate partner homicide. Am J Epidemiol 2018;187:1449-55.

76. Zeoli AM, Webster DW. Effects of domestic violence policies, alcohol taxes and police staffing levels on intimate partner homicide in large US cities. Inj Prev 2010;16:90-5. 